\title{
EDITORIAL
}

\section{Prezados Leitores}

Nos últimos 6 anos enfrentei o desafio de conduzir a revista Produção, um dos principais veículos de divulgação da produção acadêmica em Engenharia de Produção. Contei nesse período com a colaboração da nossa comunidade acadêmica, o que permitiu que atingíssemos uma série de conquistas.

Quando começamos o trabalho em 2002, a revista Produção publicava apenas dois números por ano, e como havia apresentado alguns problemas de atraso nas edições, o número de submissões estava baixo. Nesse primeiro ano tivemos como meta regularizar os números e a periodicidade, com o intuito de atrair a submissão de artigos e a confiança da comunidade no processo editorial. A resposta da comunidade foi imediata e já em 2003, pudemos ampliar o número de edições por volume para 3, o que era requisito mínimo para ingresso do periódico nas principais bases científicas. Desde então o número de submissões e de artigos publicados aumentou muito, dos 44 artigos submetidos em 2002, saltamos para uma média de 144 artigos submetidos por ano, nos últimos três anos. O volume 12 inicial foi composto de 11 artigos em 144 páginas, que confrontado com os números do volume 17 (42 artigos em 624 páginas), ajuda a demonstrar a evolução da Revista.

Alguns pontos ajudaram a consolidar o periódico, dentre eles destacamos o ingresso na base eletrônica de dados Scielo, em 2006, e na rede de serviços SibiNet/ USP, em 2007. Embora a revista Produção seja impressa sua presença nas bases científicas ajuda a difusão do conhecimento gerado pela nossa comunidade acadêmica.

Contudo, muitos desafios ainda estão por vir e tenho certeza que nas mãos da Professora Linda Lee Ho, renomada pesquisadora da área de qualidade, que me substitui na editoria, os prognósticos são os mais favoráveis para revista Produção.

Gostaria de agradecer a nossa comunidade de Engenharia de Produção pelo apoio recebido nesse seis anos e de todos aqueles que ajudaram nesse processo de consolidação da revista Produção, autores, avaliadores, corpo editorial e editores associados, além de nosso suporte administrativo que contou com várias colaboradoras nesses seis anos. Finalmente, destaco o apoio decisivo do Departamento de Engenharia de Produção da EPUSP, da Fundação Vanzolini e da ABEPRO, durante toda a minha gestão.

Marly Monteiro de Carvalho

Editora - 2002 a 2007 